Dhaka Univ. J. Biol. Sci. 24(2): 121-129, 2015 (July)

\title{
PREVALENCE, CHARACTERIZATION AND ANTIBIOTIC SUSCEPTIBILITY OF VIBRIO PARAHAEMOLYTICUS ISOLATED FROM FISHES AND SHELLFISHES OF COASTAL REGIONS OF BANGLADESH
}

\author{
Md. Manirul Haque, Anwar Hossain, Shankar Chandra MandaL ${ }^{*}$, Mohammad \\ SHAMSUR RAHMAN AND Zahid Hayat MAHMUd ${ }^{1}$ \\ Department of Fisheries, University of Dhaka, Dhaka-1000, Bangladesh
}

Key words: Prevalence, Characterization, Antibiotic susceptibility, Vibrio parahaemolyticus

\begin{abstract}
Occurrence of Vibrio parahaemolyticus in fishes and shellfishes of coastal regions of Bangladesh was investigated. Fish and shellfish samples were collected from three coastal areas, namely Kuakata, Chittagong and Cox's Bazar. Thirty five $V$. parahaemolyticus strains were isolated from 33 finfish and 6 shellfish samples where all the isolates were th positive which was species specific gene and no isolate had possessed the virulence gene encoding $t d h$. Overall prevalence rate of $V$. parahaemolyticus in fish sample was $45.45 \%$; having $18.75 \%$ from Kuakata, 22.22\% from Chittagong and $62.5 \%$ from Cox's Bazar. Fifty per cent shellfish were found to be positive for $V$. parahaemolyticus. Antibiotic susceptibility of the isolated strains was carried out against 11 antibiotics where the isolates were sensitive to the tested antibiotics except metronidazole $(50 \mu \mathrm{g})$ and nalidixic acid $(30 \mu \mathrm{g})$. Presence of this pathogenic organism in fish and shellfish could pose a serious threat to fish industry as well as human health hazard in Bangladesh.
\end{abstract}

\section{Introduction}

Vibrio parahaemolyticus, a halophilic bacterium, is a contributory agent of seafoodrelated gastroenteritis over the world which is now recognized as one of the most important food-borne pathogens, causing approximately half of food poisoning outbreaks in Asian countries like Korea, Taiwan, Japan, Vietnam, and other south-east Asian countries ${ }^{(1)}$. It forms a part of the indigenous microflora of aquatic habitats at various salinities and is the major causative agents for some of the most serious diseases in fishes, shellfishes, shrimps and even human ${ }^{(2)}$. Thermostable direct hemolysin (TDH) and TDH-related hemolysin (TRH) encoded by $t d h$ and $t r h$ genes, respectively are wellknown two major virulence factors for the pathogenesis of $V$. parahaemolyticus ${ }^{(3)}$. Although most of the $V$. parahaemolyticus isolates from the environmental and seafood samples are $t d h$ and $t r h$ negative, some investigations reported the presence of $t d h$ or $t r h$ genes in the isolates from seafood products $(3,4)$.

*Author for correspondence: <shankar@du.ac.bd>. ${ }^{1}$ Centre for Food and Waterborne Diseases, Environmental Microbiology Laboratory (EML), International Centre for Diarrhoeal Disease Research, Bangladesh (icddr,b), Bangladesh. 
As $V$. parahaemolyticus has affinity to saline water, upcoming climatic changes and subsequent increase in salinity with saline water intrusion will make this pathogen more available in inner Bangladesh coasts. This bacterium is often isolated from seafood including shrimp, crab, oyster and clam due to its halophilic characteristics. Other than shellfish, finfishes are also vulnerable to $V$. parahaemolyticus and frequently consumed by the inhabitants of these coastal areas(5). Moreover, increasingly, there have been more reports of antibiotic resistance in Vibrio species. Emergence of microbial resistance to multiple drugs is a serious clinical problem in the treatment, increasing the fatality rate in human ${ }^{(6)}$. But effective studies have not been carried out to spot $V$. parahaemolyticus in finfish from coastal regions of Bangladesh yet. Present study was thus carried out to investigate the prevalence and characterization of $V$. parahaemolyticus in fish and shellfish of coastal regions of Bangladesh.

\section{Materials and Methods}

A total of 33 different finfish and 6 shellfish with three replicates were collected from Kuakata sea beach, Chittagong and Cox's Bazar BFDC Fisheries market (Table 1) which are the most economically important species from coastal regions of Bangladesh.

Samples were collected during March to June, 2013. After collection, the samples were stored in the refrigerator at $-20^{\circ} \mathrm{C}$ and were processed within 24 hours. The muscle, gill and intestine were separated aseptically following the method of American Public Health Association (APHA) (7). In case of shellfish only muscle sample was taken for microbial analysis. Then samples were homogenized with phosphate buffer solution (PBS) using homogenizer. One hundred $\mu \mathrm{l}$ of homogenized samples were spreaded on TCBS and CV plate and incubated for $18-24$ hours at $37^{\circ} \mathrm{C}$. Green colonies from TCBS plate and violet colonies from $\mathrm{CV}$ plates were suspected for $V$. parahaemolyticus ${ }^{(8)}$. Suspected characteristic colonies subcultured on gelatin agar (GA) plates. After incubation, the colonies showing gelatinase activity were subcultured on TCBS and CV plate following patch inoculation technique for further confirmation. The presence of cytochrome oxidase was detected by Kovacs' oxidase test ${ }^{(9)}$. Colonies green on TCBS, violet on $\mathrm{CV}$ plate, gelatinase positive and cytochrome oxidase positive were then subjected to biochemical test ${ }^{(2)}$. Salt tolerance $(0,6.5$ and $8 \%$ salt $[\mathrm{w} / \mathrm{v}]$ with $1 \%$ peptone supplement) of isolates were also observed.

DNA was extracted from biochemically identified positive strains using heat treatment. Multiplex PCR amplification was performed according to Bej et al.(10). PCR primer for th was F-tlh: 5'-AAAGCGGATTATGCAGAAGCACTG-3', R-tlh: 5'-GCTA CTTTCTAGC ATTTTCTCTGC -3' and PCR primer for $t d h$ was F-tdh: 5'-GTAA AGGTCTCTGACTTT TGGAC-3', R-tdh: 5'-TGGAATAGAACCTTCATCTTCACC-3'. PCR amplification of the target DNA was carried out in a thermal cycler (BIO RAD, PTC0200G, USA). The amplification of the target genes through PCR was determined by gel 
electrophoresis in 1\% agarose. During gel electeophoresis a $100 \mathrm{bp}$ molecular weight marker was used as standards to compare the amplicon size of the PCR products. After migration for 2 hours at 90 volts, the gel was stained with ethidium bromide and photographed in an UV-transilluminator (Alpha Innotech, SA-1000, USA).

Table 1. List of fishes and shellfishes collected from Kuakata, Chittagong and Cox's Bazar.

\begin{tabular}{llll}
\hline Sl. No. & $\begin{array}{l}\text { Fish and shellfish species } \\
\text { collected from Kuakata }\end{array}$ & $\begin{array}{l}\text { Fish species collected } \\
\text { from Chittagong }\end{array}$ & $\begin{array}{l}\text { Fish and shellfish species } \\
\text { collected from Cox's Bazar }\end{array}$ \\
\hline Name of fishes & & \\
\hline 1 & Gastrophysus lunaris & Tenualosa ilisha & Tenualosa ilisha \\
2 & Tenualosa ilisha & Megalaspis cordyla & $\begin{array}{l}\text { Megalaspis cordyla } \\
\text { Johnius belangeri }\end{array}$ \\
3 & Secutor ruconius & Johnius belangeri & Polynemus paradiseus \\
4 & Brachypleur novazeelandia & Rita rita & Rastrelliger kanagurta \\
5 & Epinephelus megachir & Gudusia chapra & Dasyatis benenttii \\
6 & Carangoides malabericus & Eleotris fusca & Sphyrna blochii \\
7 & Mugil corsula & Scoliodon sorrakowah & Glossogobius giuris \\
8 & Panna microdon & Lepturacanthus savala & \\
9 & Eleutheronema tetradactylum & Argyrops spinifer & \\
10 & Cynoglossus versicolor & & \\
11 & Mystus bleekeri & & \\
12 & Dasyatis zurgei & & \\
13 & Colisa fasciatus & & \\
14 & Sillago domina & & \\
15 & Eleotris butis & & \\
16 & Johnius dussumieri & & \\
\hline Name of shellfishes & & \\
\hline 1 & Matuta planipes & & \\
2 & Penulirus polyphagus & & \\
3 & Penaeus monodon & Ocypoda ceratopthalma & \\
5 & Penaeus indicus & & \\
\hline & & & \\
\hline
\end{tabular}

Antibiotic susceptibility was carried out using the disc diffusion method. Procedures were based on the standardization of disc agar diffusion method of the National Committee for Clinical Laboratory Standards for antimicrobial susceptibility tests ${ }^{(11)}$. Isolates were inoculated on Mular Hinton Broth (Hi-Media, M173-500G, India) and incubated for 6 hours. The bacterial suspension was then inoculated onto the surface of the Muller-Hinton agar using sterile cotton swabs, which were then left to dry for 10 minutes. The antimicrobial sensitivity discs (Hi-Media, India) were applied on the agar 
surface. The discs used in the study were Ampicillin (10 $\mu \mathrm{g})$, chloramphenicol (30 $\mu \mathrm{g})$, erythromycin $(15 \mu \mathrm{g})$, gentamicin $(10 \mu \mathrm{g})$, nitrofurantoin $(300 \mu \mathrm{g})$, oxolinic acid $(20 \mu \mathrm{g})$, tetracycline $(30 \mu \mathrm{g})$, metronidazole $(50 \mu \mathrm{g})$, nalidixic acid (30) and ciprofloxacin $(5 \mu \mathrm{g})$. The plates were incubated for $18-24 \mathrm{hrs}$ at $37^{\circ} \mathrm{C}$ and then the zone of inhibition was measured.

\section{Results and Discussion}

In recent years Vibrio parahaemolyticus has been emerged as a pandemic pathogen causing seafood related gastroenteritis worldwide and responsible for most of the diarrhoeal diseases occur in the third world country like Bangladesh and India ${ }^{(12)}$. In this study $35 \mathrm{~V}$. parahaemolyticus strains were isolated from 35 finfish and 7 shellfish species based on phenotypic and PCR characterization (Table 2, Fig. 1).

Table 2. Phenotypic characterization of the isolated strains of V. parahaemolyticus.

\begin{tabular}{|c|c|c|c|}
\hline \multicolumn{2}{|c|}{ Phenotypic characters } & Properties of isolated strain & $\begin{array}{c}\text { Properties of ATCC } 43996 \\
\text { strain }\end{array}$ \\
\hline \multicolumn{2}{|c|}{ Colonies on CV plate } & Violet & Violet \\
\hline \multicolumn{2}{|c|}{ Colonies on TCBS plate } & Green & Green \\
\hline \multicolumn{2}{|c|}{ Growth on GA plate with salt } & Showed gelatinase activity & Showed gelatinase activity \\
\hline \multicolumn{2}{|c|}{ Growth on GA plate without salt } & No growth & No growth \\
\hline \multirow[t]{4}{*}{ Salt tolerance } & $0 \%$ & No growth & No growth \\
\hline & $3 \%$ & Growth & Growth \\
\hline & $8 \%$ & Growth & Growth \\
\hline & $10 \%$ & No growth & No growth \\
\hline
\end{tabular}

All the isolates were positive for th which is specific for $V$. parahaemolyticus. No toxigenic strain of $V$. parahaemolyticus was found in the present study (Fig. 1).

Among 16 fish species sampled from Kuakata, $V$. parahaemolyticus was found only in the muscle of Mystus bleekeri $\left(3.8 \pm 0.4 \times 10^{3} \mathrm{cfu} / \mathrm{g}\right)$, gill of Secutor ruconius $\left(1.6 \pm 0.9 \times 10^{3}\right.$ $\mathrm{cfu} / \mathrm{g})$ and Eleutheronema tetradactylum $\left(1.1 \pm 0.8 \times 10^{3} \mathrm{cfu} / \mathrm{g}\right)$ (Table 3). Besides, off 5 shellfish species $V$. parahaemolyticus was detected in Matuta planipes and Penaeus monodon. No $V$. parahaemolyticus was observed in other fish and shellfish species collected from Kuakata.

Eighteen $V$. parahaemolyticus isolates were obtained from 18 fish and 6 shellfish species collected from Kuakata (Table 4). The highest numbers of isolate (9 isolates) were obtained from the muscle of fish and shellfish which was about $60 \%$ of total isolates and the lowest was gained from gill which was about $40 \%$ of total. No isolate was obtained from intestine of fish from Kuakata (Table 4). 


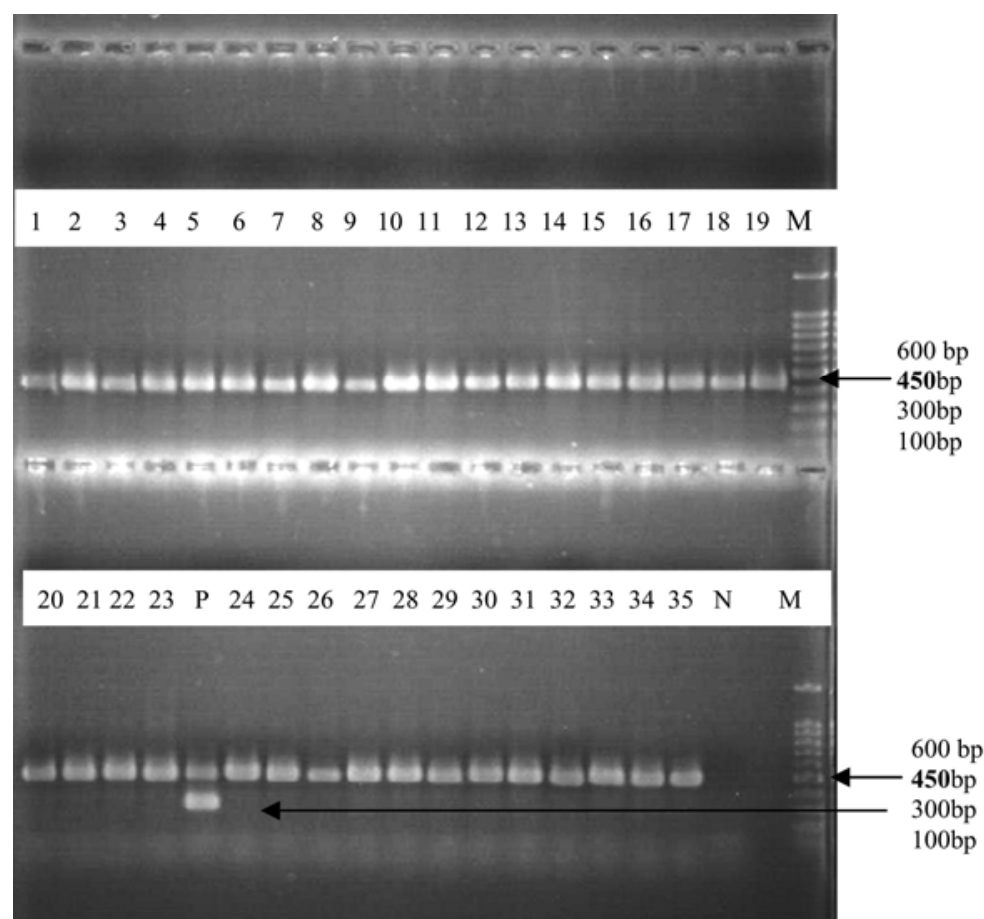

Fig. 1. PCR amplification of isolated strains from fish and shellfish showed th and $t d h$ genes that is species-specific for $V$. parahaemolyticus. Lane P, positive control; Lane N, negative control, Escherichia coli; Lane M, 100 bp molecular weight marker; Lane 1-35, V. parahaemolyticus strains.

Table 3. Prevalence of Vibrio parahaemolyticus (cfu/g) (mean \pm SEM) in the various organs of fish sampled from three coastal areas.

\begin{tabular}{lllll}
\hline \multirow{2}{*}{ Coastal areas } & Name of fish/Shellfish & \multicolumn{3}{l}{ Organs of fish } \\
\cline { 3 - 5 } & Secutor ruconius & Muscle & Gill & Intestine \\
\hline \multirow{4}{*}{ Kuakata } & Eleutheronema tetradactylum & $\mathrm{ND}$ & $1.6 \pm 0.9 \times 10^{3}$ & $\mathrm{ND}$ \\
& Mystus bleekeri & $3.8 \pm 0.4 \times 10^{3}$ & $\mathrm{ND}$ & $\mathrm{ND}$ \\
& Matuta planipes & $4.0 \pm 0.1 \times 10^{2}$ & - & $\mathrm{ND}$ \\
& Penaeus monodon & $4.9 \pm 0.04 \times 10^{3}$ & - & - \\
Chittagong & Tenualosa ilisha & $3.5 \pm 0.6 \times 10^{3}$ & $\mathrm{ND}$ & - \\
\hline \multirow{6}{*}{ Cox's Bazar } & Gudusia chapra & $2.7 \pm 0.5 \times 10^{3}$ & $1.4 \pm 0.2 \times 10^{4}$ & $2.5 \pm 0.3 \times 10^{4}$ \\
\hline & Tenualosa ilisha & $\mathrm{ND}$ & $5.6 \pm 1.2 \times 10^{2}$ & $\mathrm{ND}$ \\
& Polynemus paradiseus & $2.3 \pm 1.4 \times 10^{2}$ & $\mathrm{ND}$ & $\mathrm{ND}$ \\
& Rastrelliger kanagurta & $\mathrm{ND}$ & $5.3 \pm 1.7 \times 10^{2}$ & $\mathrm{ND}$ \\
& Dasyatis benenttii & $4.6 \pm 1.2 \times 10^{2}$ & $\mathrm{ND}$ & $\mathrm{ND}$ \\
& Sphyrna blochii & $\mathrm{ND}$ & $1.3 \pm 0.8 \times 10^{2}$ & $\mathrm{ND}$ \\
\hline
\end{tabular}

ND: Not detected. 
Nine fish species collected from Chittagong, were analyzed in the present study where V.parahaemolyticus was found in all the organs of Gudusia chapra and in the muscle of Tenualosa ilisha (Table 3). On the other hand, no V. parahaemolyticus was detected in other fishes sampled from Chittagong. Eight isolates were obtained from 2 fish species sampled from Chittagong (Table 4).

Prevalence of $V$. parahaemolyticus was higher in fish sampled from Cox's Bazar. Of 8 fish species, V. parahaemolyticus was found in 5 species (Table 3). On the other hand, one shellfish species was analyzed where bacterial load was $3.0 \pm 0.5 \times 10^{2} \mathrm{cfu} / \mathrm{g}$. In Cox's Bazar a total of 12 isolates were obtained from 8 fish species and one species of shellfish (Table 4).

Table 4. Isolates of Vibrio parahaemolyticus in the various organs of fish sampled from three coastal areas.

\begin{tabular}{|c|c|c|c|c|c|}
\hline \multirow[t]{2}{*}{ Coastal areas } & \multirow[t]{2}{*}{ Name of fish/Shellfish } & \multicolumn{3}{|c|}{ Organs of fish } & \multirow[t]{2}{*}{ Total } \\
\hline & & Muscle & Gill & Intestine & \\
\hline \multirow{6}{*}{ Kuakata } & Secutor ruconius & 0 & 3 & 0 & 3 \\
\hline & Eleutheronema tetradactylum & 0 & 3 & 0 & 3 \\
\hline & Mystus bleekeri & 3 & 0 & 0 & 3 \\
\hline & Matuta planipes & 3 & - & - & 3 \\
\hline & Penaeus monodon & 3 & - & - & 3 \\
\hline & Total & 9 & 6 & 0 & 15 \\
\hline \multirow{3}{*}{ Chittagong } & Tenualosa ilisha & 2 & 0 & 0 & 2 \\
\hline & Gudusia chapra & 2 & 2 & 2 & 6 \\
\hline & Total & 4 & 2 & 2 & 8 \\
\hline \multirow{7}{*}{ Cox's Bazar } & Tenualosa ilisha & 0 & 2 & 0 & 2 \\
\hline & Polynemus paradiseus & 2 & 0 & 0 & 2 \\
\hline & Rastrelliger kanagurta & 0 & 2 & 0 & 2 \\
\hline & Dasyatis benenttii & 2 & 0 & 0 & 2 \\
\hline & Sphyrna blochii & 0 & 2 & 0 & 2 \\
\hline & Penaeus monodon & 2 & - & - & 2 \\
\hline & Total & 6 & 6 & 0 & 12 \\
\hline
\end{tabular}

In the current study, overall prevalence rate of $V$. parahaemolyticus in fish sample was 45.45\% (15/33); having 18.75\% (3/16) from Kuakata, 22.22\% (2/9) from Chittagong and $62.5 \%(5 / 8)$ from Cox's Bazar. In a study, Sanjeev reported 35 to $55 \%$ prevalence in marine and brackish water fish in India ${ }^{(13)}$. Yang et al. revealed $19.0 \%$ prevalence of $V$. parahaemolyticus from seafood samples in China ${ }^{(14)}$. These studies support the findings of the present study. Previous study reported the incidence of $V$. parahaemolyticus highest in intestine, least in external surface and moderate in gills of the fish ${ }^{(15)}$. However, Natarajan 
et al. showed that $V$. parahaemolyticus was quite high in the gills of planktivores ${ }^{(16)}$. In the present study similar numbers of isolated strains were obtained from muscle (11 isolates), gill (14 isolates) and intestine (2 isolates) of fish. However, prevalence of $V$. parahaemolyticus in the muscle of different fish was higher than gill and intestine which may be due to the suitability of the bacteria to adhere in muscle. From the muscle of shellfish 8 isolates were obtained.

Around $18 \%$ isolated strains of $V$. parahaemolyticus were resistant to amphicillin and all the strains were sensitive to the chloramphenicol $(30 \mu \mathrm{g})$, nitrofurantoin (300 $\mu \mathrm{g})$ ciprofloxacin $(5 \mu \mathrm{g})$ and polymyxin B $(300 \mu \mathrm{g})$ (Table 5). In case of other antibiotics, variable susceptibility was observed. Most of the isolates were sensitive to the tested antibiotics. In this study no resistance was observed for polymyxin B, ciprofloxacin and chloramphenicol. Similar result was observed in the shrimp industries of Cox's Bazar (17). Oxytetracycline and erythromycin are commonly used antibiotics in Bangladesh and these drugs mainly defer plasmid-mediated resistance in aquatic bacteria ${ }^{(18)}$. In present study $10 \%$ of the isolates of $V$. parahaemolyticus showed resistance against oxytetracycline and ampicillin. Since FDA legalized oxytetracycline in addition to four more drugs for use in US aquaculture but it is essential to control their use in prescribed doses for safe use in Bangladesh ${ }^{(19)}$. The present study also recommends two more drugs - polymyxin B and ciprofloxacin that can be considered for controlling vibriosis, provided the drugs are discharged in appropriate doses once the target pathogens are identified.

Table 5. Percentage of resistance of Vibrio parahaemolyticus $(n=35)$ against 11 antibiotics.

\begin{tabular}{lc}
\hline Antibiotics & Number of resistant strains (\%) \\
\hline Ampicillin $(10 \mu \mathrm{g})$ & $6(17.14)$ \\
Chloramphenicol $(30 \mu \mathrm{g})$ & $0(0.0)$ \\
Erythromycin $(15 \mu \mathrm{g})$ & $9(25.71)$ \\
Gentamicin $(10 \mu \mathrm{g})$ & $14(40.0)$ \\
Nitrofurantoin $(300 \mu \mathrm{g})$ & $0(0.0)$ \\
Oxolinic acid $(20 \mu \mathrm{g})$ & $17(48.57)$ \\
Tetracycline $(30 \mu \mathrm{g})$ & $14(40.0)$ \\
Metronidazole $(50 \mu \mathrm{g})$ & $23(65.71)$ \\
Nalidixic acid $(30 \mu \mathrm{g})$ & $25(71.43)$ \\
Ciprofloxacin $(5 \mu \mathrm{g})$ & $0(0.0)$ \\
Polymyxin B $(300 \mu \mathrm{g})$ & $0(0.0)$ \\
\hline
\end{tabular}

In spite of being a halophilic bacterium, V. parahaemolyticus prefers low salinity for optimal growth and is capable of spreading inland to freshwater, indicated by outbreaks of diarrhea caused by V. parahaemolyticus in Dhaka, Bangladesh and Kolkata, India (12). The existence of $V$. parahaemolyticus in this region is indicated by past records for 
Bangladesh, India and Thailand(3,12). The high degree of divergence demonstrated by Bengal strains of $V$. parahaemolyticus is in agreement with many studies reporting similar results for other regions ${ }^{(1,12)}$.

Though no isolate was TDH (virulent gene for $V$. parahaemolyticus) positive in the present study, nevertheless, it may be expressed in future which would be a destructive situation for the fish industry as well as for the poor people along the coastal region in Bangladesh.

\section{References}

1. Wong HC, SH Liu and DP Liu 1999. Incidence of highly genetically diversified Vibrio parahaemolyticus in seafood imported from Asian countries. Int. J. Food Microbiol. 52: 181-188.

2. Colwell RR, PA West, D Maneval, EF Remmers, EL Ellion and NE Carlson 1984. Ecology of pathogenic vibrios in Chesapeake Bay. In: Vibrios in the Environment (RR Colwell Ed.). John Wiley and Sons, New York. pp. 367-387.

3. Nishibuchi M and JB Kaper 1995. Thermostable direct hemolysin gene of Vibrio parahaemolyticus: a virulence gene acquired by a marine bacterium. Infect. Immun. 63: 2093-2099.

4. Roque A, C Lopez-Joven, B Lacuesta, L Elandaloussi, S Wagley, MD Furones, I Ruiz-Zarzuela, I De Blas, R Rangdale and B Gomez-Gil 2009. Detection and identification of tdh- and trhpositive Vibrio parahaemolyticus strains from four species of cultured bivalve mollusks on the Spanish Mediterranean coast. Appl. Environ. Microbiol. 75: 7574-7577.

5. Cabrera-Garcia ME, C Vazquez-Salinas and EI Quinones-Ramirez 2004. Serologic and molecular characterization of Vibrio parahaemolyticus strains isolated from seawater and fish products of the Gulf of Mexico. Appl. Environ. Microbiol. 70: 6401-6406.

6. Shaw KS, RER Goldstein, X He, JM Jocobs, BC Crump and AR Sapkota 2014. Antimicrobial susceptibility of Vibrio vulnificus and Vibrio parahaemolyticus recoverded from recreational and commercial areas of Chesapeake Bay and Maryland coastal Bays. Plos One 9: 11.

7. APHA (American Public Health Association) 1998. Standard Methods for the Examination of Water and Wastewater, 20 $0^{\text {th }}$ ed. (Clesceri LS, AE Greenberg and AD Eaton Eds), American Public Health Association. Washington, DC.

8. Mahmud ZH, A Kassu, A Mohammad, M Yamato, NA Bhuiyan, GB Nair and F Ota 2006. Isolation and molecular characterization of toxigenic Vibrio parahaemolyticus from the Kii Channel, Japan. Microbiol. Res. 161: 25-37.

9. Kovacs N 1956. Identification of Pseudomonas pyocyanea by the oxidase reaction. Nature 178: 703.

10. Bej AK, DP Patterson, CW Brasher, MC Vickery, DD Jones and CA Kaysner 1999. Detection of total and hemolysin-producing Vibrio parahaemolyticus in shellfish using multiplex PCR amplification of $t l, t d h$ and $t r h$. J. Microbiol. Method. 36 (3): 215-225.

11. Finegold SM and WJ Martin 1982. Diagnostic Microbiology $6^{\text {th }}$ Ed, The C.B. Mosby Company, London.

12. Nair GB and JC Hormazabal 2005. The Vibrio parahaemolyticus pandemic. Rev. Chilena. Infectol. 22: 125-130. 
13. Sanjeev S 2002. Pathogenic halophilic vibrios in seafoods. In: Quality Assurance in Seafood Processing. Central Institute of Fisheries Technology and Society of Fisheries Technologists (India), Cochin. pp. 252.

14. Yang Z, X Jiao, X Zhou, G Cao, W Fang and R Gu 2008. Isolation and molecular characterization of Vibrio parahaemolyticus from fresh, low temperature preserved, dried and salted seafood products in two coastal areas of eastern China. Int. J. Food Microbiol. 125: 279-285.

15. Sanjeev S and J Stephen 1995. Occurrence of enteropathogenic, kanagawa-positive strains of Vibrio parahaemolyticus in fresh finfish and shellfish. Fishery Tech. 32: 64-66.

16. Natarajan AV, RK Saxena and NK Srivastava 1979. Experiments in raising quality fish seed in floating nurseries and its role in aquaculture in India. p. 45-49. International Workshop on Cage and Pen Culture, Tigbauan, Philippines (mimeo).

17. Rahman S, SN Khan, MN Naser and MM Karim 2010. Isolation of Vibrio spp. from Penaeid Shrimp Hatcheries and Coastal Waters of Cox's Bazar, Bangladesh. Asian J. Exp. Biol. Sci. 1: 288-293.

18. Graslund S and BE Bengtsson 2001. Chemicals and biological products used in south-east Asian shrimp farming and their potential impact on the environment - A review. Sci. Environ. 280: 93-131.

19. FDA (Food and Drug Administration) 1997. Guide for the Control of Molluscan Shellfish. Public Health Services. Natl. Shellfish Sanitation Program. Washington, D.C. U.S. Department of Health and Human Services. pp. 325. 